\title{
DETERMINING EFFICIENCY OF TOURISM SECTOR IN CERTAIN EUROPEAN COUNTRIES AND REGIONS BY APPLYING DEA ANALYSIS
}

\author{
Vladimir PAVKOVIĆ ${ }^{*}$, Goran JEVIĆ ${ }^{2}$, Jelena JEVIĆ ${ }^{3}$, Phong Thanh NGUYEN ${ }^{4,5}$ and \\ Cipriana SAVA6 \\ ${ }^{1}$ Academy of Applied Studies Belgrade - Department College of Tourism, Zoran Đinđić Boulevard 152a, \\ Belgrade, Serbia, vladimirp@visokaturisticka.edu.rs \\ 2 Academy of Applied Studies Belgrade - Department College of Tourism, Zoran Đinđić Boulevard 152a, \\ Belgrade, Serbia, jevicg@visokaturisticka.edu.rs \\ ${ }^{3}$ Academy of Applied Studies Belgrade - Department College of Tourism, Zoran Đinđić Boulevard 152a, \\ Belgrade, Serbia, jelenajevic1984@gmail.com \\ ${ }^{4}$ Department of Project Management, Ho Chi Minh City Open University, Ho Chi Minh City, Vietnam, \\ phong.nt@ou.edu.vn \\ ${ }_{5}^{5}$ Professional Knowledge \& Project Management Research Team (K2P), Ho Chi Minh City Open \\ University, Ho Chi Minh City, Vietnam, phong.nt@ou.edu.vn \\ ${ }^{6}$ Faculty of Tourism and Commercial Management, Christian University "D.Cantemir" Timisoara, \\ Romania, cipriana.sava@gmail.com
}

\begin{abstract}
The paper presents research results of efficiency of tourism sector in certain European countries and regions obtained by applying DEA method. The primary goal of the paper is to determine to what extent tourism sector in certain European countries and regions is efficient in relation to set parameters, while the secondary goal is aimed at providing recommendations for its improvement. In relation to this, the methodology of the DEA analysis is based on the input and output parameters which were used to determine the efficiency. The input parameters included: number of hotels and similar accommodation capacities, number of rooms and number of bed places, whereas the output parameters included: number of inbound tourists, number of bed-nights and tourism expenditure during their stay abroad. One of the conclusions of the paper is that the total efficiency was shown in Croatia, Belgium, and Denmark, while the technical efficiency was also present in North Macedonia, France, Malta, the Netherlands, Portugal, and Spain.
\end{abstract}

Keywords: DEA analysis, tourism, efficiency of tourism, European regions and countries

Original scientific paper

Received: 24.09.2021

Accepted: 21.10.2021

Available online: 28.10 .2021

${ }^{*}$ Corresponding author 


\section{Introduction}

Tourism represents an immense and fast-growing industry (Tooman, 1997), while its international scope has a positive impact on the long-term economic growth through currency flow, infrastructure investment, stimulation of other sectors and income generating (Schubert et al., 2011). Underlying its relevance to the increase of the economic benefits of local population, Webster and Ivanov (2014) regard the importance of tourism through the assumption that more competitive destinations will attract a larger number of tourists as high spenders, which is followed by the increase in GDP and economic growth in the destination. Considering that tourism is regarded as income generating and increasing job opportunities (Pablo-Romero \& Molina, 2013), tourism in Europe and the world represents an important strategy for economic growth (Antonakakis et al., 2015).

In the contemporary global tourism market, competitiveness of destinations is more and more gaining prominence as a relevant factor in market positioning. In this regard, the efficiency of tourism sector has a great role in the development and competitiveness. Cracolici et al. (2008) underline that, in long term, whether a destination will be successful depends greatly on the efficient management of input in order to obtain the desired output. In the similar vein, Corne (2015) considers hospitality as one of the key sectors in tourism and, therefore, hotels need to be competitive in order to attract tourists and thus determining efficiency in hospitality is an important aspect of researching efficiency of tourism.

Great number of authors in their papers consider the importance of determining efficiency of tourism with an additional stress on the importance of the DEA analysis (Chaabuni, 2019; Barros, 2005; Barros \& Santos, 2006; Pérez-Rodríguez \& Acosta-González, 2007; Peypoch \& Solonandrasana, 2008; Wang et al., 2006; Chiang et al., 2004; Lozano \& Gutiérrez, 2011; Hadad et al., 2012; Liang \& Yang, 2012; Martín et al., 2017; Soysal-Kurt, 2017). The advantage of the DEA analysis is reflected in the analysis of multiple inputs and outputs (Chaabuni, 2019; Barros \& Santos, 2006; Mitrović et al., 2017; Wang et al., 2006; Chiang et al., 2004; Martín et al., 2017; Savić et al., 2012), as the model is flexible enough to be adapted to different needs of evaluation in tourism (Chaabuni, 2019). Considering the above, Martić and Savić (2001) regard DEA analysis as one of the most significant method in efficiency research.

Chaabuni (2019) used the following parameters: number of inbound tourists, employment in tourism sector and GDP in tourism sector for the needs of DEA analysis in determining efficiency in tourism in certain regions in China. Barros and Santos (2006) applied DEA analysis to measure efficiency of Portuguese hotels, with inputs (number of full-time staff, remuneration, property value, running costs and external costs) and outputs (sales, number of guests and number of bednights). Barros (2005) used DEA analysis in order to determine the efficiency of the Portuguese hotel chain Enatur, with inputs: full-time staff, remuneration, property value, running costs, external costs, and outputs: sales, number of guests and number of bed-nights. Chiang et al. (2004) applied DEA analysis to estimate the efficiency of hotels in Taiwan, with four inputs (number of hotel rooms, dining capacity, number of staff and total hotel costs) and three outputs (yielding index, profit from food and beverages, other profits excluding rooms, food and beverages). Similarly, Wang et al. (2006) conducted DEA method to analyse the efficiency in 49 hotels in Taiwan by using four inputs (full-time booking staff, number of rooms, surface of dining facilities, and full-time food and beverage staff) and three outputs (room sales, food and beverage sales, other profits). Lozano and Gutiérrez (2011) used DEA analysis to determine efficiency of tourism sector in $25 \mathrm{EU}$ member states, with four inputs (number of bed places in offer, employment level, climatic advantage, and natural and cultural heritage) and three outputs (number of visitors, number of bed-nights, and inbound tourist receipts). Soysal-Kurt (2017) applied DEA method to 
analyse efficiency of 29 European countries using three inputs (tourism costs, number of staff, number of bed places) and three outputs (tourist receipts, number of inbound tourists, and number of bed-nights).

In this context, the research of the paper is based on DEA analysis, DEA CCR method, DEA BCC method, tourism and its efficiency, and efficiency of tourism in certain countries and regions in Europe. The paper is structured into six parts. After the introductory part with theoretical overview of references, the second part explains the methodology of the research. The third part describes the research and data used in the analysis. The fourth part analyses and discusses the results, and the fifth represents the concluding argument. The sixth part consists of references and lists of tables and figures.

\section{Methodology}

Martić and Savić (2001) state that the DEA analysis was applied for the first time by Charnes et al. in 1978 in order to estimate the relative efficiency of organisational DMUs - Decision Making Units, which use multiple inputs for producing multiple outputs, while the efficiency of a unit is estimated as the ratio between the weighted sum of outputs and weighted sum of inputs. Mitrović et al. (2017) underline that the DEA method is designed for ranking different decision-making units according to their relative efficiency, while this method designates weight to each decisionmaking unit separately, as stated by Savić et al. (2012).

\section{Efficiency $=$ weighted sum of output/weighted sum of input}

CCR ratio model calculates total technical efficiency that includes pure technical efficiency and efficiency as the outcome of different volumes of business. The model leans to maximize the value $h_{k}$ by designating value to the variables $u_{r}$ and $v_{i}$ by each unit in order to present it in the best light. And for the $k^{\text {th }} \mathrm{DMU}$ for which the maximum efficiency is needed $0<h_{k} \leq 1$ is applied. If the value of $h_{k}$ in the aim function equals 1 , then the $k^{\text {th }}$ DMU is relatively efficient, and if it is under 1, DMUk is relatively inefficient and the value $h_{k}$ shows how much this unit needs to decrease its inputs in percentage. DMUk can be considered completely efficient only if the reach of other DMUs do not prove that some of its inputs or outputs could be improved without jeopardizing some of its remaining inputs or outputs. Namely, if the unit is efficient, it means that its optimal values for weighted coefficients no other unit can achieve greater value for that input, while this cannot be applied to inefficient units (Savić, 2016: 22). According to (Savić, 2016: 23), CCR model is as follows:

$$
\text { (Max) } h_{k}=\frac{\sum_{r=1}^{S} u_{r} y_{r k}}{\sum_{i=1}^{m} v_{i} x_{i k}}
$$

p.o.

$$
\begin{gathered}
\frac{\sum_{r=1}^{S} u_{r} y_{r j}}{\sum_{i=1}^{m} v_{i} x_{i j}} \leq 1, \quad \mathrm{j}=1,2, \ldots . \mathrm{n} \\
\mathrm{u}_{\mathrm{r}} \geq 0 \quad \mathrm{r}=1,2, \ldots . \mathrm{s} \\
v_{i} \geq 0 \quad \mathrm{i}=1,2, \ldots . . \mathrm{m}
\end{gathered}
$$

with:

$h_{k}$ - relative efficiency of the $k^{\text {th }} \mathrm{DMU}$;

$n$ - number of DMUs to be compared;

$m$-number of inputs; 
$s$ - number of outputs;

$u_{r}$ - weighted coefficient for output $r$;

$v_{i}$ - weighted coefficient for input $i$.

The first expansion of the basic CCR DEA model was introduced by Banker, Charnes and Cooper in 1984. BCC model measures the pure technical efficiency, i.e., it measures efficiency while ignoring the influence of the volume of business by comparing the $j^{\text {th }} \mathrm{DMU}$ only with units of the similar scale. Scale efficiency showing whether the unit operates with optimal scale can be obtained by dividing the measure of efficiency from the CCR model (total technical efficiency) by the measure of efficiency from the BCC model (pure technical efficiency) (Ćiraković et al., 2014: 1034). Compared to the primal CCR model, the primal BCC model includes additional variable $u_{*}$ which defines the position of auxiliary hyperplane placed either at or above each DMU in the analysis (Savić, 2016: 26). According to Savić (2016: 27), BCC model is as follows:

$$
h_{k}=\sum_{r=1}^{s} u_{r} y_{r k}+u_{*}
$$

p.o.

$$
\begin{gathered}
\sum_{i=1}^{m} v_{i} x_{i k}=1 \\
\sum_{r=1}^{s} u_{r} y_{r j}-\sum_{i=1}^{m} v_{i} x_{i j}+u_{*} \leq 0, \mathrm{j}=1,2, \ldots . \mathrm{n} \\
u_{r} \geq \varepsilon_{r} \quad \mathrm{r}=1,2, \ldots . \mathrm{s} \\
v_{i} \geq \varepsilon_{r} \quad \mathrm{i}=1,2, \ldots . \mathrm{m}
\end{gathered}
$$

\section{Data}

The aim of the paper is to analyse efficiency of tourism sector in certain countries and regions by applying the DEA analysis, the DEA CCR and DEA BCC models in particular. The countries are systemized into five groups: countries in transition (Serbia, Croatia, North Macedonia, Montenegro, Romania), Scandinavian countries (Sweden, Norway, Denmark), Eastern European countries (Hungary, Poland, Czechia), Mediterranean countries (France, Greece, Cyprus, Malta, Italy, Portugal, Spain) and Central and Western European countries (Slovenia, Austria, Belgium, Germany, the Netherlands).

DEA analysis in the paper includes three inputs and three outputs (Table 1). As inputs the following were used: number of hotels and similar accommodation capacities, number of rooms, number of bed places. As outs the following were used: number of inbound tourists, number of bed-nights and tourism expenditure in dollars. The total number of DMUs is 23 .

The data presented are from 2017 with the data regarding the number of inbound tourists and tourist expenditure in dollars obtained from The World Bank (2017), while the number of bed-nights, number of hotels and similar capacities, number of rooms, and number of bed places are taken from Eurostat (2017). DEA analysis was conducted by using the following software: DEA model = DEA-Solver LV8.0/ CCR(CCR-O) and DEA model = DEA-Solver LV8.0/ BCC (BCCO). 
Table 1. Input and output parameters

\begin{tabular}{|c|c|c|}
\hline TYPE OF PARAMETER & PARAMETER & ACRONYM \\
\hline Input parameter (IP) & $\begin{array}{c}\text { Number of hotels and similar } \\
\text { accommodation capacities }\end{array}$ & NHOT \\
\hline Input parameter (IP) & Number of rooms & NRM \\
\hline Input parameter (IP) & Number of bed places & NBP \\
\hline Output parameter (OP) & Number of inbound tourists & NIT \\
\hline Output parameter (OP) & Number of bed-nights & NBN \\
\hline Output parameter (OP) & Tourism expenditure in million dollars & TEXP \\
\hline
\end{tabular}

Table 2. Countries in transition

\begin{tabular}{|c|c|c|c|c|c|c|}
\hline & IP & IP & IP & OP & OP & OP \\
\hline COUNTRY & NHOT & NRM & NBP & NIT & NBN & TEXP \\
\hline Serbia & 919 & 44.813 & 106.029 & 1.497 .000 & 8.312 .000 & 1.705 \\
\hline Croatia & 1.037 & 79.984 & 166.485 & 15.593 .000 & 86.095 .000 & 11.128 \\
\hline $\begin{array}{c}\text { North } \\
\text { Macedonia }\end{array}$ & 274 & 9.335 & 20.500 & 631.000 & 1.975 .000 & 331 \\
\hline Montenegro & 331 & 16.626 & 36.333 & 1.877 .000 & 3.890 .000 & 1.109 \\
\hline Romania & 2.766 & 114.389 & 219.750 & 10.926 .000 & 26.916 .000 & 2.999 \\
\hline
\end{tabular}

Sources: The World Bank (2017); Eurostat (2017a); Eurostat (2017b)

Table 3. Scandinavian Countries

\begin{tabular}{|c|c|c|c|c|c|c|}
\hline & IP & IP & IP & OP & OP & OP \\
\hline COUNTRY & NHOT & NRM & NBP & NIT & NBN & TEXP \\
\hline Sweden & 2.025 & 122.948 & 245.963 & 7.054 .000 & 58.683 .000 & 14.205 \\
\hline Norway & 1.058 & 87.578 & 188.235 & 6.252 .000 & 33.290 .000 & 6.515 \\
\hline Denmark & 559 & 46.653 & 93.386 & 11.743 .000 & 32.158 .000 & 7.969 \\
\hline
\end{tabular}

Sources: The World Bank (2017); Eurostat (2017a); Eurostat (2017b)

Table 4. Eastern European Countries

\begin{tabular}{|c|c|c|c|c|c|c|}
\hline & IP & IP & IP & OP & OP & OP \\
\hline COUNTRY & NHOT & NRM & NBP & NIT & NBN & TEXP \\
\hline Hungary & 2.184 & 73.736 & 181.240 & 5.650 .000 & 31.609 .000 & 8.453 \\
\hline Poland & 4.064 & 162.512 & 335.917 & 18.258 .000 & 83.881 .000 & 14.083 \\
\hline Czechia & 5.967 & 137.318 & 317.361 & 10.160 .000 & 53.219 .000 & 7.693 \\
\hline \multicolumn{7}{|c|}{ Sources: The World Bank (2017); Eurostat (2017a); Eurostat (2017b) }
\end{tabular}

Table 5. Mediterranean Countries

\begin{tabular}{|c|c|c|c|c|c|c|}
\hline & IP & IP & IP & OP & OP & OP \\
\hline COUNTRY & NHOT & NRM & NBP & NIT & NBN & TEXP \\
\hline France & 18.391 & 660.017 & 1.320 .034 & 86.861 .000 & 433.059 .000 & 69.894 \\
\hline Greece & 9.772 & 409.873 & 794.507 & 27.194 .000 & 111.271 .000 & 18.820 \\
\hline Cyprus & 794 & 41.805 & 84.977 & 3.652 .000 & 16.781 .000 & 3.128 \\
\hline Malta & 183 & 18.785 & 42.973 & 2.274 .000 & 9.580 .000 & 1.746 \\
\hline Italy & 32.988 & 1.086 .910 & 2.239 .446 & 58.253 .000 & 420.629 .000 & 44.548 \\
\hline Portugal & 2.538 & 153.971 & 363.088 & 15.432 .000 & 72.036 .000 & 21.099 \\
\hline Spain & 19.630 & 924.174 & 1.916 .607 & 81.786 .000 & 471.200 .000 & 68.437 \\
\hline \multicolumn{7}{|l|}{ Sources: The World Bank (2017); Eurostat (2017a); Eurostat (2017b) } \\
\end{tabular}


Table 6. Central and Western European Countries

\begin{tabular}{|c|c|c|c|c|c|c|}
\hline & IP & IP & IP & OP & OP & OP \\
\hline COUNTRY & NHOT & NRM & NBP & NIT & NBN & TEXP \\
\hline Slovenia & 698 & 22.908 & 46.639 & 3.586 .000 & 12.460 .000 & 2.952 \\
\hline Austria & 12.153 & 291.046 & 609.393 & 29.460 .000 & 121.127 .000 & 22.408 \\
\hline Belgium & 1.517 & 58.968 & 129.456 & 8.385 .000 & 38.677 .000 & 13.750 \\
\hline Germany & 32.749 & 963.339 & 1.811 .615 & 37.452 .000 & 401.163 .000 & 56.173 \\
\hline Netherlands & 3.636 & 124.049 & 270.098 & 17.924 .000 & 111.698 .000 & 20.352 \\
\hline
\end{tabular}

Sources: The World Bank (2017); Eurostat (2017a); Eurostat (2017b)

Table 7. Statistical parameters of input/output values

\begin{tabular}{|c|c|c|c|c|c|c|}
\hline & NHOT & NRM & NBP & NIT & NBN & TEXP \\
\hline Max & 32.988 & 1.086 .910 & 2.239 .446 & 86.861 .000 & 471.200 .000 & 69.894 \\
\hline Min & 183 & 9.335 & 20.500 & 631.000 & 1.975 .000 & 331 \\
\hline Average & 6792.739 & $245.727,695$ & 501.740 .521 & 20082608.695 & 114769956,521 & 18.239 \\
\hline SD & 9694.241900 & 323415.774 & 646000.193 & 23852915.612464 & 149766822.1801 & 20597152967.0444 \\
& 16443 & 545833 & 646348 & & 97 & \\
\hline
\end{tabular}

Source: The authors' calculation

Table 8. Corelation between input/output values

\begin{tabular}{|c|c|c|c|c|c|c|}
\hline & NHOT & NRM & NBP & NIT & NBN & TEXP \\
\hline NHOT & 1 & 0.9745489973 & 0.9677518353 & 0.7865771185 & 0.9163588739 & 0.8451916805 \\
\hline NRM & 0.9745489973 & 1 & 0.9985177958 & 0.8636684876 & 0.9612375899 & 0.8998522441 \\
\hline NBP & 0.9677518353 & 0.9985177958 & 1 & 0.8725874349 & 0.9620633309 & 0.8999361209 \\
\hline NIT & 0.7865771185 & 0.8636684876 & 0.8725874349 & 1 & 0.9461086740 & 0.9535251978 \\
\hline NBN & 0.9163588739 & 0.9612375899 & 0.9620633309 & 0.9461086740 & 1 & 0.9739951312 \\
\hline TEXP & 0.8451916805 & 0.8998522441 & 0.8999361209 & 0.9535251978 & 0.9739951312 & 1 \\
\hline
\end{tabular}

Source: The authors' calculation

\section{Results and Discussion}

The research has shown that among the countries in transition (Table 9), according to the set criteria, the efficiency is present only in Croatia, while all the other countries show a high level of inefficiency, with Serbia having the highest level of inefficiency (0.2094). DEA analysis has shown that Serbia, in order to reach efficiency, should simultaneously decrease the number of hotels by $8.6 \%$ and number of bed places by $9.8 \%$, maintain the current number of rooms, increase the number of inbound tourists by $412 \%$, the number of bed-nights by $377.64 \%$ and their expenditure by the same percentage.

Table 9. Efficiency in countries in transition according to CCR model

\begin{tabular}{|c|c|c|c|c|c|c|c|}
\hline COUNTRY & $\begin{array}{c}\text { NHOT } \\
\text { Diff. (\%) }\end{array}$ & $\begin{array}{c}\text { NRM } \\
\text { Diff. (\%) }\end{array}$ & $\begin{array}{c}\text { NBP } \\
\text { Diff. (\%) }\end{array}$ & $\begin{array}{c}\text { NIT } \\
\text { Diff. (\%) }\end{array}$ & $\begin{array}{c}\text { NBN } \\
\text { Diff. (\%) }\end{array}$ & $\begin{array}{c}\text { TEXP } \\
\text { Diff. (\%) }\end{array}$ & EFFICIENCY \\
\hline Serbia & -8.594 & 0 & -9.846 & 412.059 & 377.64 & 377.64 & 0.2094 \\
\hline Croatia & 0 & 0 & 0 & 0 & 0 & 0 & 1 \\
\hline $\begin{array}{c}\text { North } \\
\text { Macedonia }\end{array}$ & -58.594 & 0 & -8.215 & 257.728 & 257.728 & 366.146 & 0.2795 \\
\hline Montenegro & -39.814 & 0 & -8.401 & 122.958 & 194.61 & 156.083 & 0.4485 \\
\hline Romania & -52.444 & -4.028 & 0 & 152.909 & 181.142 & 525.28 & 0.3954 \\
\hline
\end{tabular}

Source: The authors' calculation 
Among Scandinavian countries (Table 10), the efficiency is shown in Denmark, while Sweden (0.6492) and Norway (0.4731) should take measures to reach efficiency. In this regard, Sweden should keep the current number of hotels and bed places but to reduce number of rooms by $4.3 \%$ and increase the number of inbound tourists by $231 \%$, and their bed-nights and expenditure by $54 \%$.

Table 10. Efficiency in Scandinavian countries according to CCR model

\begin{tabular}{|c|c|c|c|c|c|c|c|}
\hline COUNTRY & $\begin{array}{c}\text { NHOT } \\
\text { Diff. (\%) }\end{array}$ & $\begin{array}{c}\text { NRM } \\
\text { Diff. (\%) }\end{array}$ & $\begin{array}{c}\text { NBP } \\
\text { Diff. } \\
(\%)\end{array}$ & $\begin{array}{c}\text { NIT } \\
\text { Diff. (\%) }\end{array}$ & $\begin{array}{c}\text { NBN } \\
\text { Diff. (\%) }\end{array}$ & $\begin{array}{c}\text { TEXP } \\
\text { Diff. (\%) }\end{array}$ & EFFICIENCY \\
\hline Sweden & 0 & -4.326 & 0 & 230.949 & 54.047 & 54.047 & 0.6492 \\
\hline Norway & 0 & -1.868 & -7.391 & 219.927 & 111.355 & 111.355 & 0.4731 \\
\hline Denmark & 0 & 0 & 0 & 0 & 0 & 0 & 1 \\
\hline
\end{tabular}

Eastern European countries show a high percentage of inefficiency according to the DEA analysis (Table 11). Hungary (0.5542) and Poland (0.5537) show similar results while Czechia stays behind with 0.3793 . In order to improve efficiency, Hungary should reduce the number of hotels (25\%) and bed places (12\%) while keeping the same number of rooms. Simultaneously, it should increase the number of inbound tourists by nearly 105\% along with the increase of their bed-nights and expenditure by $80.6 \%$.

Table 11. Efficiency in Eastern European countries according to CCR model

\begin{tabular}{|c|c|c|c|c|c|c|c|}
\hline COUNTRY & $\begin{array}{c}\text { NHOT } \\
\text { Diff. (\%) }\end{array}$ & $\begin{array}{c}\text { NRM } \\
\text { Diff. (\%) }\end{array}$ & $\begin{array}{c}\text { NBP } \\
\text { Diff. } \\
\text { (\%) }\end{array}$ & $\begin{array}{c}\text { NIT } \\
\text { Diff. (\%) }\end{array}$ & $\begin{array}{c}\text { NBN } \\
\text { Diff. (\%) }\end{array}$ & $\begin{array}{c}\text { TEXP } \\
\text { Diff. (\%) }\end{array}$ & EFFICIENCY \\
\hline Hungary & -25.198 & 0 & -11.98 & 104.837 & 80.449 & 80.449 & 0.5542 \\
\hline Poland & -43.913 & -0.317 & 0 & 80.602 & 80.602 & 80.602 & 0.5537 \\
\hline Czechia & -68.29 & 0 & -9.826 & 163.651 & 163.651 & 163.651 & 0.3793 \\
\hline
\end{tabular}

Source: The authors' calculation

As presented in Table 12, none of the Mediterranean countries is efficient according to the set criteria for estimating efficiency. The best result is achieved by Malta with 0.7555, followed by Portugal by 0.7165 and France with 0.7068 . The least efficiency is in Greece with 0.3175 . In order to become efficient, Malta needs to reduce the number of rooms by $21.5 \%$ and bed places by $30 \%$ while keeping the existing number of hotels. Simultaneously, the number of inbound tourists to Malta should be increased by $47 \%$, along with increasing the number of bed-nights and tourist expenditure by $32 \%$.

Table 12. Efficiency in Mediterranean countries according to CCR model

\begin{tabular}{|c|c|c|c|c|c|c|c|}
\hline COUNTRY & $\begin{array}{c}\text { NHOT } \\
\text { Diff. (\%) }\end{array}$ & $\begin{array}{c}\text { NRM } \\
\text { Diff. (\%) }\end{array}$ & $\begin{array}{c}\text { NBP } \\
\text { Diff. (\%) }\end{array}$ & $\begin{array}{c}\text { NIT } \\
\text { Diff. (\%) }\end{array}$ & $\begin{array}{c}\text { NBN } \\
\text { Diff. (\%) }\end{array}$ & $\begin{array}{c}\text { TEXP } \\
\text { Diff. (\%) }\end{array}$ & EFFICIENCY \\
\hline France & -49.592 & -4.212 & 0 & 41.478 & 41.478 & 41.478 & 0.7068 \\
\hline Greece & -50.227 & -5.239 & 0 & 214.922 & 214.922 & 216.555 & 0.3175 \\
\hline Cyprus & -19.907 & -2.741 & 0 & 117.434 & 117.434 & 117.434 & 0.4599 \\
\hline Malta & 0 & -21.542 & -30.138 & 46.881 & 32.367 & 32.367 & 0.7555 \\
\hline Italy & -57.715 & -1.014 & 0 & 260.062 & 175.324 & 236.012 & 0.3632 \\
\hline Portugal & 0 & 0 & -12.426 & 115.352 & 44.994 & 39.559 & 0.7165 \\
\hline Spain & -32.951 & -0.967 & 0 & 111.614 & 100.014 & 100.014 & 0.5 \\
\hline
\end{tabular}

Source: The authors' calculation

Analysing countries of Central and Western Europe (Table 13), according to the set criteria efficiency in tourism sector is shown only in Belgium while the Netherlands with 0.962 is quite 
close. In order to achieve efficiency, the Netherlands should reduce the number of hotels by $41 \%$ and number of bed places by $2.6 \%$, while keeping the number of current number of rooms. Simultaneously, the number of inbound tourists should be increased by $23 \%$, with increasing their bed-nights and expenditure by approximately $4 \%$.

Table 13. Efficiency in Central and Western European countries according to CCR model

\begin{tabular}{|c|c|c|c|c|c|c|c|}
\hline COUNTRY & $\begin{array}{c}\text { NHOT } \\
\text { Diff. (\%) }\end{array}$ & $\begin{array}{c}\text { NRM } \\
\text { Diff. (\%) }\end{array}$ & $\begin{array}{c}\text { NBP } \\
\text { Diff. (\%) }\end{array}$ & $\begin{array}{c}\text { NIT } \\
\text { Diff. (\%) }\end{array}$ & $\begin{array}{c}\text { NBN } \\
\text { Diff. (\%) }\end{array}$ & $\begin{array}{c}\text { TEXP } \\
\text { Diff. (\%) }\end{array}$ & EFFICIENCY \\
\hline Slovenia & -50.704 & -1.131 & 0 & 37.065 & 37.065 & 37.065 & 0.7296 \\
\hline Austria & -66.758 & 0 & -1.585 & 110.156 & 110.156 & 110.156 & 0.4758 \\
\hline Belgium & 0 & 0 & 0 & 0 & 0 & 0 & 1 \\
\hline Germany & -63.125 & -10.026 & 0 & 341.92 & 125.679 & 125.679 & 0.4431 \\
\hline Netherlands & -41.227 & 0 & -2.656 & 22.729 & 3.946 & 3.946 & 0.962 \\
\hline \multicolumn{78}{|c|}{}
\end{tabular}

Overall comparison (Table 14 and Figure 1) DEA analysis has shown that out of all considered countries, only three (Croatia, Denmark and Belgium) have efficiency of tourist sector according to the set criteria. Quite close is also the Netherlands with 0.962 .

Table 14. Overall ranking of countries according to CCR model

\begin{tabular}{|c|c|c|c|}
\hline DMU & COUNTRY & EFFICIENCY & RANKING \\
\hline B & Croatia & 1 & 1 \\
\hline H & Belgium & 1 & 1 \\
\hline V & Denmark & 1 & 4 \\
\hline O & Netherlands & 0.962 & 5 \\
\hline M & Malta & 0.7555 & 6 \\
\hline E & Slovenia & 0.7296 & 7 \\
\hline P & Portugal & 0.7165 & 8 \\
\hline I & France & 0.7068 & 9 \\
\hline R & Sweden & 0.6492 & 10 \\
\hline U & Hungary & 0.5542 & 11 \\
\hline W & Poland & 0.5537 & 12 \\
\hline Q & Spain & 0.5 & 13 \\
\hline G & Austria & 0.4758 & 14 \\
\hline S & Norway & 0.4731 & 16 \\
\hline L & Cyprus & 0.4599 & 17 \\
\hline D & Montenegro & 0.4485 & 18 \\
\hline J & Germany & 0.4431 & 19 \\
\hline F & Romania & 0.3954 & 20 \\
\hline T & Czechia & 0.3793 & 22 \\
\hline N & Italy & 0.3632 & 23 \\
\hline K & Greece & 0.3175 & \\
\hline C & North Macedonia & 0.2795 & 0.2094 \\
\hline A & Serbia & & \\
\hline
\end{tabular}

Source: The authors' calculation 


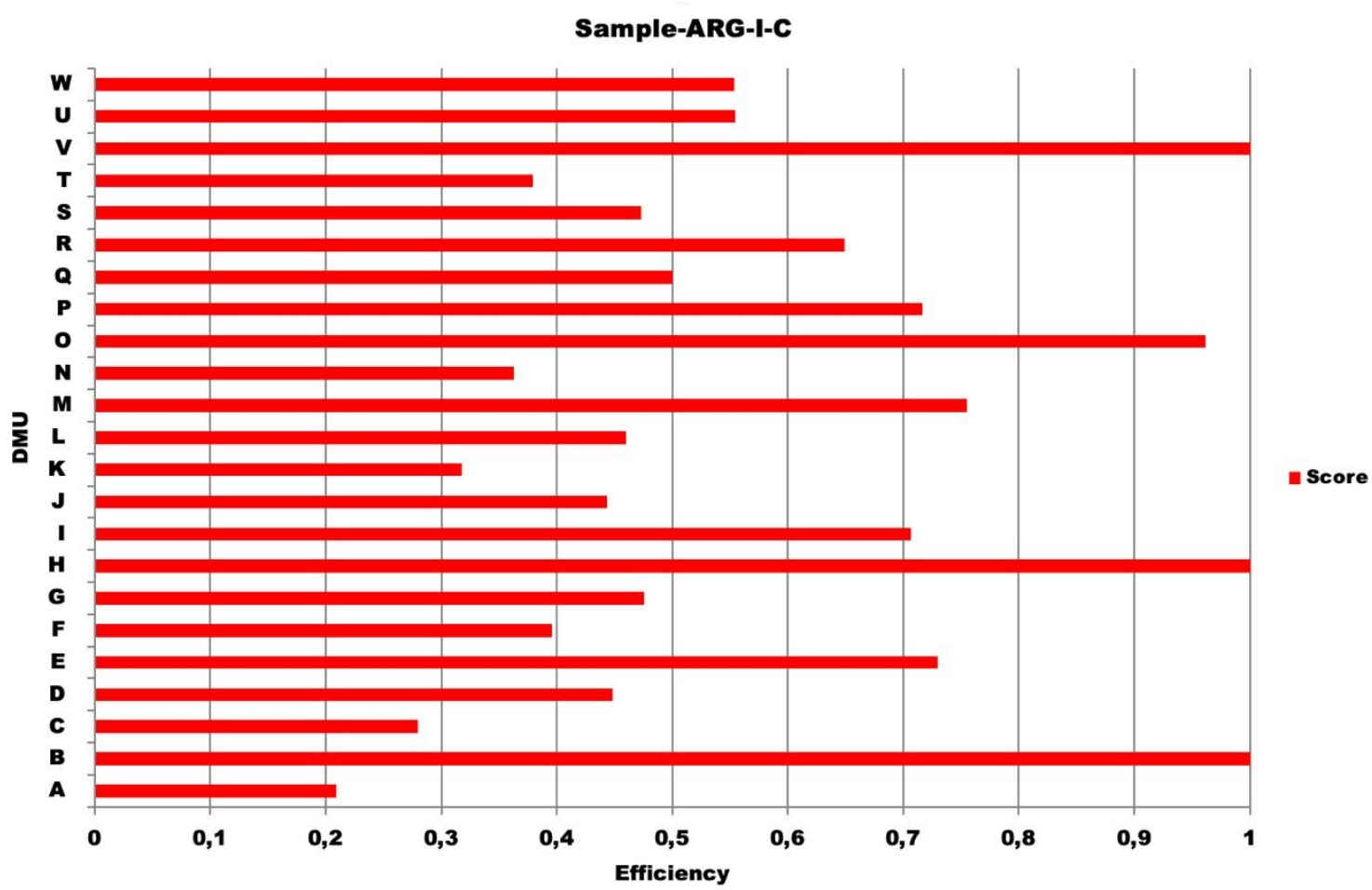

Figure 1. Total efficiency in countries according to CCR model Source: The authors' calculation

After applying the DEA analysis BCC model (Table 15 and Figure 2), it can be observed that there is a larger number of countries showing efficiency in tourist sector according to the set criteria: Croatia, North Macedonia, Belgium, France, Malta, the Netherlands, Portugal, Spain, and Denmark. According to the BCC model, quite close to the efficiency are Slovenia, Italy, Germany, and Sweden.

Table 15. Overall ranking of countries according to BCC model

\begin{tabular}{|c|c|c|c|c|c|c|c|c|c|}
\hline DMU & COUNTRY & $\begin{array}{c}\text { NHO } \\
\text { T } \\
\text { Diff. } \\
(\mathbf{\%})\end{array}$ & $\begin{array}{c}\text { NRM } \\
\text { Diff. } \\
(\mathbf{\%})\end{array}$ & $\begin{array}{c}\text { NBP } \\
\text { Diff. } \\
\mathbf{( \% )}\end{array}$ & $\begin{array}{c}\text { NIT } \\
\text { Diff. } \\
(\mathbf{\%})\end{array}$ & $\begin{array}{c}\text { NBN } \\
\text { Diff. } \\
(\mathbf{\%})\end{array}$ & $\begin{array}{c}\text { TEXP } \\
\text { Diff. } \\
(\%)\end{array}$ & EFFICIENCY & $\begin{array}{c}\text { RANKIN } \\
\text { G }\end{array}$ \\
\hline B & Croatia & 0 & 0 & 0 & 0 & 0 & 0 & 1 & 1 \\
\hline C & $\begin{array}{c}\text { North } \\
\text { Macedonia }\end{array}$ & -0.001 & 0 & 0 & 0.003 & 0.003 & 0.004 & 1 & 1 \\
\hline H & Belgium & 0 & 0 & 0 & 0 & 0 & 0 & 1 & 1 \\
\hline I & France & 0 & 0 & 0 & 0 & 0 & 0 & 1 & 1 \\
\hline M & Malta & 0 & 0 & 0 & 0.001 & 0 & 0 & 1 & 1 \\
\hline O & Netherlands & -0.001 & 0 & 0 & 0 & 0 & 0 & 1 & 1 \\
\hline P & Portugal & 0 & 0 & 0 & 0.001 & 0 & 0 & 1 & 1 \\
\hline Q & Spain & 0 & 0 & 0 & 0 & 0 & 0 & 1 & 1 \\
\hline V & Denmark & 0 & 0 & 0 & 0 & 0 & 0 & 1 & 1 \\
\hline E & Slovenia & - & -3.38 & 0 & 3.985 & 3.985 & 3.985 & 0.9617 & 10 \\
\hline N & Italy & - & -14.972 & - & 40.399 & 12.024 & 53.627 & 0.8927 & 11 \\
\hline J & Germany & - & -8.891 & 0 & 120.76 & 15.786 & 22.29 & 0.8637 & 12 \\
\hline R & Sweden & 40.725 & -11.858 & 0 & 94.412 & 18.204 & 18.204 & 0.846 & 13 \\
\hline W & Poland & -5.698 & 0 & -2.381 & 40.81 & 40.81 & 40.81 & 0,7102 & 14 \\
\hline
\end{tabular}




\begin{tabular}{|c|c|c|c|c|c|c|c|c|c|}
\hline G & Austria & $\begin{array}{c}- \\
36.937\end{array}$ & 0 & -4.472 & 41.458 & 58.425 & 45.675 & 0.7069 & 15 \\
\hline D & Montenegro & -0.399 & 0 & -4.384 & 49.282 & 102.36 & 64.408 & 0.6699 & 16 \\
\hline S & Norway & 0 & -12.89 & - & 119.16 & 73.069 & 73.069 & 0.5778 & 17 \\
\hline U & Hungary & - & 0 & -11.16 & 89.829 & 77.993 & 77.993 & 0.5618 & 18 \\
\hline F & Romania & - & -3.978 & 0 & 78.303 & 172.91 & 378.43 & 0.5608 & 19 \\
\hline K & Greece & 0 & -9.255 & -5.965 & 89.252 & 134.32 & 116.29 & 0.5284 & 20 \\
\hline L & Cyprus & - & -3.392 & 0 & 99.398 & 99.398 & 99.398 & 0.5015 & 21 \\
\hline T & Czechia & - & 0 & - & 122.10 & 122.10 & 122.10 & 0.4502 & 22 \\
\hline A & Serbia & -4.02 & 0 & -9.605 & 385.46 & 346.26 & 346.26 & 0.2241 & 23 \\
\hline
\end{tabular}

Source: The authors' calculation

Sample-ARG-I-C

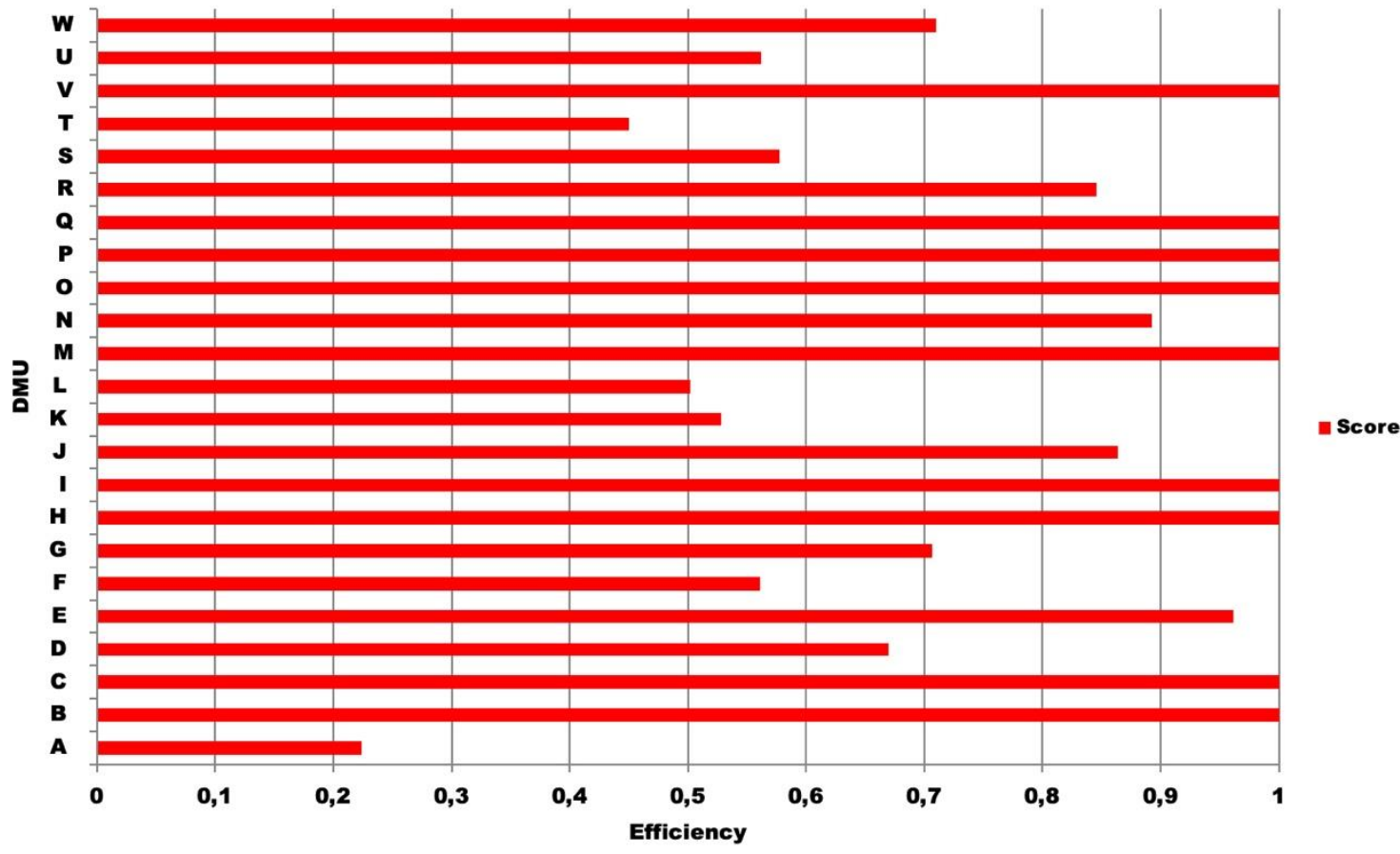

Figure 2. Total efficiency in countries according to BCC model Source: The authors' calculation

\section{Conclusion}

Since an ever-increasing number of people wants to travel, especially to a foreign country, tourism represents one of the fastest-growing industry in the world. Tourism in many countries represents a valuable source of income, especially foreign currency, job opportunities and development of local, regional, and national economy. Bearing this fact in mind, there is a strong necessity to make the tourist sector as efficient as possible. In that sense, it is crucial to measure efficiency of the whole tourist sector, as well as its process and activities separately.

There are numerous models for measuring efficiency in tourism, DEA being one of the most common. This analysis is very significant as it provides results of efficiency in tourist sector based 
on which corrections can be made in order to develop strategy and tactics for achieving optimal efficiency. The paper measures efficiency in tourist sector based on inputs (number of hotels and similar accommodation capacities, rooms, and bed places) and outputs (number of inbound tourists, number of bed-nights and tourist expenditure in dollars). In order to make the analysis relevant, countries were divided into five regions: countries in transition, Scandinavian countries, Mediterranean countries, Eastern European countries, and Central and Western European countries.

Taking the overall data into consideration, it can be concluded that tourist sector in the majority of European countries cannot achieve total efficiency when the set criteria are regarded. Based on the results from DEA CCR analysis, the only countries to be considered efficient are Croatia, Belgium, and Denmark, while the results obtained from DEA BCC analysis are considerably more favourable, so that North Macedonia, France, Malta, the Netherlands, Portugal, and Spain can be considered efficient, in addition to the above-mentioned countries.

Results from DEA CCR analysis of tourist sector show that the countries in transition have a very low level of efficiency, with the exception of Croatia. All the other countries show results below 0.5, while Serbia is the least efficient with 0.2094. Among the Scandinavian countries, the only country showing efficiency is Denmark, while Sweden is relatively inefficient (0.6492). None of the Eastern European countries is efficient in tourism according to the DEA CCR analysis, while Belgium is efficient among the Central and Western European countries, while the Netherlands is quite close $(0,962)$. The Mediterranean countries do not show efficiency in tourism according to the results from DEA CCR analysis, while Malta (0.7555), Portugal (0.7165) and France (0.7068) show less inefficiency in comparison to the other countries. Among the countries in transition, efficiency is shown in Croatia and North Macedonia, while among the Scandinavian countries, Denmark is efficient, and Sweden is the closest with 0.846. The results of DEA BCC analysis of Eastern European countries show that none of the countries is efficient (with Poland the closest to it with 0.7102). In Central and Western Europe, countries considered efficient are Belgium and the Netherlands (the closest to efficiency are Slovenia with 0.9617 and Germany with 0.8637). Analysing results of DEA BCC analysis of the Mediterranean countries, efficiency is found in France, Malta, Portugal, and Spain, while Italy is the closest with 0.8927 .

The contribution of this research is reflected in the presentation of one of the possibilities of applying DEA analysis in modern tourism. Also, through discussion, results and conclusion, destination management was given a clear recommendation to improve the efficiency of tourism in their countries, taking into account the given parameters.

However, determining efficiency precisely in the whole tourist sector of these countries would imply including other parameters relevant to inbound tourism and not included in this research. In that sense, the results obtained in this analysis are to be considered within the context of the set criteria, which are connected to the influence of accommodation capacities and units on output parameters like the number of inbound tourists, number of bed-nights and tourist receipts. 


\section{References}

Antonakakis, N., Dragouni, M., \& Filis, G. (2015). How strong is the linkage between tourism and economic growth in Europe?. Economic Modelling, 44, 142-155. https://doi.org/10.1016/j.econmod.2014.10.018

Barros, C. A. P., \& Santos, C. A. (2006). The Measurement of Efficiency in Portuguese Hotels Using Data Envelopment Analysis. Journal of Hospitality \& Tourism Research, 30(3), 378-400. https://doi.org/10.1177\%2F1096348006286798

Barros, C. P. (2005). Evaluating the efficiency of a small hotel chain with a Malmquist productivity index. International Journal of Tourism Research, 7(3), 173-184. https://doi.org/10.1002/jtr.529

Chaabouni, S. (2019). China's regional tourism efficiency: A two-stage double bootstrap data envelopment analysis. Journal of Destination Marketing \& Management, 11, 183-191. https://doi.org/10.1016/j.jdmm.2017.09.002

Chiang, W., Tsai, M., \& Wang, L. S. M. (2004). A DEA evaluation of Taipei hotels. Annals of Tourism Research, 31(3), 712-715. https://doi.org/10.1016/j.annals.2003.11.001

Ćiraković, L.S., Bojović, N.J., \& Milenković, M.S. (2014). Analiza efikasNBNti autobuskog podsistema javnog transporta putnika u gradu Beogradu, korišćenjem DEA metode. Tehnika-Saobraćaj, 61, 1032-1039.

Corne, A. (2015). Benchmarking and tourism efficiency in France. Tourism Management, 51, 91-95. https://doi.org/10.1016/j.tourman.2015.05.006

Cracolici, M. F., Nijkamp, P., \& Rietveld, P. (2008). Assessment of tourism competitiveness by analysing destination efficiency. Tourism Economics, 14(2), 325-342. https://doi.org/10.5367\%2F000000008784460427

Eurostat (2017a). Nights spent in tourist accommodation establishments. https://ec.europa.eu/eurostat/statisticsexplained/images/a/ae/Nights spent in tourist accommodation establishments\%2C 2017.png; (30.08.2021.)

Eurostat (2017b). Number of establishment, bedrooms and bed-places. http://appsso.eurostat.ec.europa.eu/nui/show.do?dataset=tour cap nat\&lang=en (30.08.2021.)

Hadad, S., Hadad, Y., Malul, M., \& Rosenboim, M. (2012). The economic efficiency of the tourism industry: A global comparison. Tourism economics, 18(5), 931-940. https://doi.org/10.5367\%2Fte.2012.0165

Liang, L. T., \& Yang, J. T. (2012). Analysis of the tourism efficiency and its decomposition based on DEA. Geographical Research, 31(8), 1422-1430. https://doi.org/10.5367\%2Fte.2012.0165

Lozano, S., \& Gutiérrez, E. (2011). Efficiency analysis of EU-25 member states as tourist destinations. International Journal of Services Technology and Management, 15(1-2), $69-88$. https://doi.org/10.1504/IJSTM.2011.038663

Martić, M., \& Savić, G. (2001). An application of DEA for comparative analysis and ranking of regions in Serbia with regards to social-economic development. European Journal of Operational Research, 132(2), 343-356. https://doi.org/10.1016/S0377-2217(00)00156-9 
Martín, J. C., Mendoza, C., \& Román, C. (2017). A DEA travel-tourism competitiveness index. Social Indicators Research, 130(3), 937-957. https://doi.org/10.1007/s11205-015-1211-3

Mitrović, Z., Vujošević, M., \& Savić, G. (2017). Data envelopment analysis for evaluating serbia's health care system. Management: Journal of Sustainable Business and Management Solutions in Emerging Economies, 20(75), 39-46. https://doi.org/10.7595/management.fon.2015.0012

Pablo-Romero, M. D. P., \& Molina, J. A. (2013). Tourism and economic growth: A review of empirical literature. Tourism Management Perspectives, 8, 28-41. https://doi.org/10.1016/j.tmp.2013.05.006

Pérez-Rodríguez, J. V., \& Acosta-González, E. (2007). Cost efficiency of the lodging industry in the tourist destination of Gran Canaria (Spain). Tourism Management, 28(4), 993-1005. https://doi.org/10.1016/j.tourman.2006.08.007

Peypoch, N., \& Solonandrasana, B. (2008). Aggregate efficiency and productivity analysis in the tourism industry. Tourism Economics, 14(1), 45-56. https://doi.org/10.5367\%2F000000008783554794

Savić, G. (2016). Merenje performansi i DEA osnove. http://pa.fon.bg.ac.rs/wpcontent/uploads/2016/02/Merenje-perofrmansi-i-DEA-Osnove.pdf (31.08.2021.)

Savić, G., Makajić-Nikolić, D., i Suknović, M. (2012). AHP-DEA Measure for study program selection. Symorg 2012 - Operational Research and Quantitative Methods in Management, Belgrade 1217-1223.

Schubert, S. F., Brida, J. G., \& Risso, W. A. (2011). The impacts of international tourism demand on economic growth of small economies dependent on tourism. Tourism Management, 32(2), 377-385. https://doi.org/10.1016/j.tourman.2010.03.007

Soysal-Kurt, H. (2017). Measuring tourism efficiency of European countries by using data envelopment analysis. European Scientific Journal, ESJ, 13(10), 31. https:// doi: 10.19044/esj.2017.v13n10p31

The World Bank (2017). World Development Indicators: Travel and tourism. http://wdi.worldbank.org/table/6.14\# (30.08.2021.)

Tooman, L. A. (1997). Tourism and development. Journal of Travel Research, 35(3), 33-40. https://doi.org/10.1177\%2F004728759703500305

Wang, F. C., Hung, W. T., \& Shang, J. K. (2006). Measuring the cost efficiency of international tourist hotels in Taiwan. Tourism Economics, 12(1), 65-85. https://doi.org/10.5367\%2F000000006776387150

Webster, C., \& Ivanov, S. (2014). Transforming competitiveness into economic benefits: Does tourism stimulate economic growth in more competitive destinations?. Tourism Management, 40, 137-140. https://doi.org/10.1016/j.tourman.2013.06.003

(C) 2021 by the authors. Submitted for possible open access publication under the terms and (i) conditions of the Creative Commons Attribution (CC BY) license (http://creativecommons.org/licenses/by/4.0/). 